\title{
Analysis of Virulence Potentials of Community Acquired Staphylococcus aureus, Isolated from a Slam Population of West Bengal, India
}

\author{
Prithwiraj Mukherjee, Amit Karmakar, Smritikana Biswas, \\ Srayose De, Saikat De, Chandradipa Ghosh * \\ Department of Human Physiology with Community Health, Vidyasagar University, \\ Medinipur-West, Pin 721102, West Bengal, India
}

\begin{abstract}
The worldwide spread of community acquired Staphylococcus aureus (CASA) skin infection is becoming an emerging problem. This study was conducted to delineate the virulence properties and characteristics of Staphylococcus aureus isolated from children belonging to low socio-economic classes in Midnapore town, West Bengal, India. Samples were collected from affected children by aseptic means from areas of infection with proper medical intervention. These samples were confirmed first as Staphylococcus aureus by PCR amplification of 16S rRNA. Further morphology, antibiotic susceptibility, capability of secreting several enzymes, biofilm forming abilities was studied. PCR was carried out for detection of the presence of enterotoxins (seA and seB), exfoliatin toxins (etA and etB) and toxic shock syndrome toxin (tss T) genes. Results reveal that 33\% community acqured Staphylococcus aureus strains were methicillin resistant and $22 \%$ were vancomycin resistant and those strains were capable of biofilm formation. Besides, all of the pathogenic and non-pathogenic strains were harboring exfoliatin toxin gene (etA). So it can be concluded that inducible multidrug resistant community acquired Staphylococcus aureus with their diverse pathogenic toxic potentials giving emerging alarm in that geographical location in India.
\end{abstract}

Keywords-Staphylococcus aureus, Staphylococcal Scalded Skin Syndrome, Staphylococcal toxins, vancomycin, biofilm.

\section{INTRODUCTION}

Staphylococcal scalded skin syndrome (SSSS) is a syndrome of acute exfoliation of the skin (Acland et al., 1999). One of two Staphylococcal exfoliatin toxin (A and B) binds to desmoglein-1 in desmosome causing it to break down. That leads to a red rash and separation of the epidermis beneath the granular cell layer (Ladhani et al., 1999; Adhisivam et al., 2006; Amagai et al., 2002). Children are more at risk because of lack of immunity and immature renal clearance capability (Baartmans et al., 2006). It is rare in adults (Cribier et al., 1994). Mortality rate from SSSS in children is very low (1-5\%), whereas in adults it is higher (20-30\%) (Chi et al., 2006). No gender predilection was documented in children. In adults, the male-to-female ratio was approximately 2:1 (El Helali et al., 2005).

Staphylococcus aureus is the leading cause for a broad spectrum of diseases that ranges from superficial skin lesions and invasive inflammations to life-threatening diseases. Toxic shock syndrome belongs to a class of toxin-mediated disease that evokes multisystem disorders in the human host due to the Staphylococcal toxic shock syndrome toxin (TSST-1) (Abdulmula et al., 2006). According to serological classification, six Staphylococcal enterotoxin (SE) group have been recognized: SEA, SEB, SEC, SED, SEE and SHE (Su et al. 1995). These enterotoxins are small peptides (26 to $29 \mathrm{kDa}$ ) and have a great deal of similarity at their amino acid level (Manisha et al., 2000). They are the main source of food poisoning and cause intensive intestinal peristalsis.

Reports are increasing implicating community-acquired multidrug resistant Staphylococcus aureus as a cause of SSSS (Ito et al., 2002). Multidrug resistant Staphylococcus aureus is thought to emerge in a community when a locally prevalent antibiotic susceptible strain acquires genetic element and utilizes mobile genetic elements and nucleotide polymorphisms to establish local and geographic niches (Kennedy et al., 2008). The formation of biofilms is also another example of a phenotypic change. Biofilm, consists of multiple layers of bacteria encased within secreted exopolysaccharide matrix material that protects the enclosed bacteria from host defenses and impedes delivery of at least some antibiotics (Stewart et al., 2002). 
CASA cases are being reported from all over the world, yet there have not been many studies regarding the actual incidence of CASA infections in people of low socioeconomic classes specifically in children community in different geographical regions in India. In this study, attempts were undertaken primarily to screen out the community-acquired Staphylococcus aureus strains from children belonging to low socioeconomic condition from Midnapore town, India. We tried to search out the presence of essential virulence genes for scalded skin syndrome in those strains and their ability of elaborating different enzymes, biofilm formation and response towards different antibiotics. Genes coding for enterotoxins and toxic shock syndrome toxin were also screened out for proper characterization of their overall virulence potential.

\section{MATERIALS AND METHODS}

\subsection{Collection of Samples and culture media:}

This study was carried out in children those had superficial skin infection of two to nine years age group from slam areas surrounding Midnapore town, West Bengal, India. Superficially scar tissues were collected using standard microbiological procedure with proper medical intervention. Samples were cultured in bacto brain heart infusion medium (HiMedia, India) overnight at $37^{\circ} \mathrm{C}$ in a shaker incubator (Scigenics Biotech, India). All bacterial samples were grown further on nutrient agar (HiMedia, India) media and purified by a single colony isolation technique on nutrient agar containing $10 \%$ sodium chloride.

\subsection{Identification of Staphylococcus aureus bacteria from purified isolates:}

Identification of Staphylococcus aureus were performed by PCR amplification of 16S rRNA. The oligonucleotide primer pairs for 16S rRNA are listed in Table1.The reaction condition used was reported previously (Astrid et al., 2004).

\subsection{Biochemical characterization of Staphylococcus aureus bacteria from identified isolates:}

The identified isolates were characterized by traditional biochemical tests, including Gram staining, catalase, coagulase, urea and gelatin hydrolysis test (Murray et al., 1978; Ronald et al., 1995; Bannerman et al., 2003). The bacterial samples were inoculated on MacConkey's agar for 24-48 hours and examined for bacterial growth.

\subsection{Test for Hemolytic ability:}

To identify the hemolytic ability, the bacterial isolates were screened on blood agar media by the method mentioned by Ronald et al., (1995).

\subsection{Antibiotic susceptibility testing:}

The antibiotic-resistance profile was determined by the Disc agar diffusion (DAD) technique (Bauer et al., 1966; Acar, 1980), using ten crucial antibiotic discs. Among those antibiotics all were obtained commercially from HiMedia, India. E. coli, an all-sensitive reference strain, was used as a quality control strain for the DAD test.

\subsection{Biofilm Assay:}

Cells from colonies grown overnight on LB agar plates at room temperature, were resuspended in LB broth to an optical density of 0.3 at $\mathrm{OD}_{600} .3 \mu 1$ of the cell suspension was added to $300 \mu 1$ of LB in $10 / 75-\mathrm{mm}$ borosilicate glass tubes. Cultures were incubated at room temperature without shaking for various times. At the desired end-point, non-adherent cells were removed by rinsing with distilled water. Biofilms were stained by the addition of $350 \mu 1$ of $1 \%$ crystal violet (Sigma, India) for $25 \mathrm{~min}$ followed by rinsing with distilled water, as described elsewhere (Watnick et al., 2001; Lauriano et al., 2004). The cell-associated dye was solubilized in $400 \mu 1$ of dimethyl sulfoxide (DMSO) and quantified by measuring the $\mathrm{OD}_{570}$ value of the resulting solution. All assays were performed in triplicate.

\subsection{Detection of enterotoxins, exfoliatin toxins and toxic shock syndrome toxin using PCR:}

Genomic DNA was prepared by modification of a method described elsewhere (Chakraborty et al., 2001). Oligonucleotide primers are listed in Table1. Those primers sequences were chosen from published primer sequences and were obtained commercially from GeNei, India. The amplification was performed in an automated thermo cycler with a hot bonnet (Eppendorf). The optimized thermal cycling conditions for multiplex PCRs were 30 cycles of denaturation at $95^{\circ} \mathrm{C}$ for $1 \mathrm{~min}$ ( $2 \mathrm{~min}$ for the first cycle), annealing at $55^{\circ} \mathrm{C}$ for $47 \mathrm{sec}$, and polymerization at $72^{\circ} \mathrm{C}$ for $1 \mathrm{~min} 37 \mathrm{sec}$ ( $5 \mathrm{~min}$ for the last cycle). For amplification the following components were used: $1.5 \mathrm{mM} \mathrm{MgCl}_{2}, 200 \mathrm{mM}$ each of dATP, dTTP, dGTP and dCTP, $2 \mathrm{mM}$ of each primer, $0.1 \mathrm{mg}$ template DNA, and $1.25 \mathrm{U}$ Taq polymerase (GeNai). For prevention of primer-dimmer formation and denaturation of template DNA, after addition of template DNA (5 to $10 \mathrm{ng}$ ), the mixture was incubated at $95^{\circ} \mathrm{C}$ for $5 \mathrm{~min}$ and stored in ice before addition of $1.25 \mathrm{U}$ of Taq DNA polymerase. Amplified products $(10 \mu \mathrm{l})$ were visualized by $1.2 \%$ agarose gel electrophoresis at $100 \mathrm{~V}$ for 1 hour. The gel was previously stained with ethidium bromide (HiMedia), and the bands were visualized under UV illumination (Eppendorf) at $254 \mathrm{~nm}$. 


\section{RESULT AND DISCUSSION}

Bullous impetigo is a common disease among children caused by Staphylococcus aureus. CASA incidence varies among country by country. Low frequency (around 1\%) found among European countries and a high frequency $(>60 \%)$ found in Asian countries (Deurenberg et al., 2007). From those community strains it was found that $19-51 \%$ strains were from the group of MRSA. Report from China in 2008 showed $10.4 \%$ of isolates from skin and soft tissue infections to be MASA (Ho et al., 2008). The rate was increased to $54.1 \%$ in the report of Yao et al. 2010. In India, Nagaraju et al. (2004) reported that an isolation rate of MRSA from community associated pyoderma to be $10.9 \%$ (Nagaraju et al., 2004).

CASA is defined as CASA isolated from outpatient with no history of hospitalization within the past one year and who presented no other established risk factors. On that background we collected a number of bacterial isolates from skin infections of children and from them through PCR analysis of 16S rRNA using specific primers we identified eighteen isolates to be Staphylococcus aureus. Those isolates produced round opaque colonies of golden yellow color and all of them were Gram positive bacteria. We did not proceed with other strains which did not give 16S rRNA amplification product. Staphylococci form an irregular cluster of cells and staphyloxanthin is responsible for its characteristics golden yellow color (Clauditz et al., 2006). For definitive characterization by using biochemical or enzyme based way, we found those strains have the ability to grow at a temperature range of 15 to 45 degrees and at $\mathrm{NaCl}$ concentrations as high as 15 percent (Duguid et al., 1996). All of them were catalase positive and fifteen of them were coagulase positive. Previous reports reveal that coagulase positive Staphylococci aureus are more virulent (Aarestrup et al., 1994; Blair, 1962; Sperber et al., 1975). The pathogenic ability of Staphylococcus aureus also depends to a small extent on their capability to degrade the RBC. For determining the pathogenic ability of the coagulase positive Staphylococcus aureus hemolysin test using blood agar media was performed and found that coagulase positive bacteria produced clearing zone surrounding their growth. In blood agar media blood was incorporated into medium to provide growth factor required by the fastidious pathway of bacteria those have hemolysing power of blood (RBC) by secreting enzyme hemolysin.

We have found that those among eighteen, sixteen Staphylococcus aureus were capable of biofilm formation and two strains were defective in that. This ability to form biofilms is of significant interest, as biofilm formation influences the efficacy of antimicrobial therapy and the subsequent outcome of an infection (Gilbert et al., 2002) This ability is also important for virulence as that helps the organism to survive within a habitat (Gotz, 2002). Staphylococcus aureus has been shown by confocal laser-scanning microscopy to form a biofilm-like glycocalyx and to congregate in microcolonies (Akiyama et al., 2003). The ica operon, which encodes a polysaccharide intercellular adhesin, is the best understood mediator of biofilm development (Cramton et al., 1999), however, ica-independent biofilm development, biofilm-associated protein (Bap) and the Staphylococcus aureus surface protein (SasG) have all been implicated in biofilm development and regulation (Cucarella et al., 2007; O'Neill et al., 2007; Corrigan et al., 2007). The Staphylococcus aureus quorum-sensing system is encoded by the accessory gene regulator (agr) locus is also involved in biofilm formation (O'Neill et al., 2007).

We have found that those isolate showing sensitive or resistance towards different antibiotic environment. Since the beginning of the antibiotic era Staphylococcus aureus has responded to the introduction of new drugs by rapidly acquiring resistance by a variety of genetic mechanisms including acquisition of extrachromosomal plasmids or other types of DNA insertion and by mutations in chromosomal genes. Aminoglycosides such as kanamycin, gentamycin, streptomycin, etc. were once effective against Staphylococcal infections until the organism evolved mechanisms to destroy the aminoglycosides action (Carter et al., 2000). The $\beta$-lactamase-resistant penicillins (methicillin, oxacillin, cloxacillin and flucloxacillin) were developed to treat penicillin-resistant Staphylococcus aureus and are still used as first-line treatment. Methicillin was the first antibiotic in this class to be used (it was introduced in 1959), but the first case of methicillin-resistant Staphylococcus aureus (MRSA) was reported in England (Jevons, 1961).

We have found $22 \%$ strains to be vancomycin resistant among these eighteen. The first case of vancomycin-intermediate Staphylococcus aureus (VISA) was reported in Japan in 1996 (Hiramatsu et al., 1997), but the first case of Staphylococcus aureus truly resistant to glycopeptides antibiotics was only reported in 2002 (Chang et al., 2003). Three cases of VRSA infection have been reported in the United States in the year 2005 (Menichetti et al., 2005). A number of studies have investigated the role of the bacterial cell wall in vancomycin susceptibility in Staphylococcus aureus (Sieradzki et al., 1999; Cui et al., 2000). Increased resistance to vancomycin in Mu50 Staphylococcus aureus was associated with increased peptidoglycan synthesis, reduced peptidoglycan cross-linking and thickening of cell wall (Cui et al., 2000). Thickening of cell walls correlated with the trapping of vancomycin in the outer layers and was considered to be the mechanism of resistance (Cui et al., 2000). Other studies have suggested that structural changes in cell wall teichoic acids may also play a role in the resistance mechanism by reducing the rate of cell wall degradation thus maintaining a correlation between wall thickness, and decreasing susceptibility to vancomycin (Sieradzki et al., 1999). 
Recently, there has been evidence to support the exchange of genetic material among VRSA bacteria (Srinivasan et al., 2002; Lowy et al., 2003; Weigal et al., 2003). Genetic analysis suggests that the in-vivo transfer of vancomycin resistance from E. faecalis to an MRSA strain occurred to produce the Michigan VRSA isolate (Weigal et al., 2003). Acquisition of the vanA gene in the Michigan isolate occurred via the interspecies transfer of Tn1546 (the vanA transposon, harboured within a multiresistant conjugative plasmid) from coisolated vancomycin-resistant E. faecalis (Weigal et al., 2003). This isolate achieved vancomycin resistance by altering the terminal peptide of D-alanyl-D-alanine to D-alanyl-D-lactate, which only occurs with exposure to low concentrations of vancomycin, and the new dipeptide seems to have a reduced affinity for vancomycin (Lowy et al., 2003).

Our data clearly show that $e t A$ gene was amplified in multiplex PCR from all of these eighteen isolates and we did not find any other toxin gene. The two ETs i.e., ETA and ETB, in conjunction or independently, are implicated in causing SSSS (Iandolo et al., 1989; Sakurai et al., 1995; Johnson et al., 1991). Reports obtained in case of strains of Staphylococcus aureus producing one or both of two immunologically distinct exfoliative toxins, ETA or ETB have also been observed to be associated with a series of impetiginous Staphylococcal diseases referred to as SSSS (Iandolo et al., 1989; Marrack et al., 1990; Lee et al., 1987). Although ETA and ETB have identical biological activity and a degree of genetic similarity (Marrack et al., 1990). The gene coding for ETA is chromosomal whereas the gene coding for ETB is plasmid linked (Lee et al., 1987; Yamaguchi et al., 2000; Endo et al., 2003; Warren et al., 1980; Yamaguchi et al., 2001). All those exfoliatin causes intraepidermal splitting of the epidermis when injected into neonatal mice (Yamaguchi et al., 2002). In Nigeria, several authors argued that exfoliatin A would be the most frequent (Adesiyun et al., 1991; Ladhani et al., 2001). The association of multi drug resistance and exfoliatin genes was common about $1.4 \%$ in Tunisia (Ben et al., 2006).

The emergence of multi-drug resistance strains in the community is a growing concern. Although hospital associated strains can be transmitted in the community, some authors argue that the increasing dominancy of multi-drug resistant strains in the community cannot be explained by the spread of hospital strains (Loughman et al., 2009). Strains in the community are often different from clinical strains and it appears to have risen outside the health care environment because of the selective pressure of antibiotics (Buckingham et al., 2004; Fridkin et al., 2005). However, lower rates of CASA observed in Europe and this is due to a better standard of hygiene and good policies in using antibiotics reduces the movement of bacteria in those communities (Trystam et al., 2002).

\section{CONCLUSSION}

We have collected a number of samples from skin and soft tissue infection from children and identified eighteen were Staphylococcus aureus by polymerase chain reaction. Those isolates have hemolytic power and can use biofilm mode of growth. We have found 33\% were MRSA and 22\% were VRSA. They were all exfoliatin toxin positive strains. This genotypic technique, however, allows the detection of gene-harboring strains independent of their expression. Hence, a positive result in the PCR is indicative only of the presence of the organism and does not indicate the viability or pathogenic toxic potential. The emergence of inducible VRSA in Midnapore, India and its intrageneric transfer is alarming. This may soon become a global problem, unless antimicrobial agents are used more prudently.

\section{ACKNOWLEDGEMENTS}

Authors are thankful to all the children for their assistance to conduct the study. We also extend thanks to all the parents, for their kind cooperation.

\section{REFERRENCES}

[1]. Acland, K.M., Darvay, A., and Griffin, C. (1999) Staphylococcal scalded skin syndrome in an adult associated with methicillin-resistant Staphylococcus aureus. Br J Dermatol.140:518-20.

[2]. Ladhani, S., Joannou, C.L., Lochrie, D.P., Evans, R.W., and Poston, S.M. (1999) Clinical, microbial, and biochemical aspects of the exfoliative toxins causing staphylococcal scalded-skin syndrome. Clin.Microbiol.Rev.12:224-42.

[3]. Adhisivam, B., and Mahadevan, S. (2006) Abscess of the nasal septum with Staphylococcal scalded skin syndrome. Indian Pediatr.43:372-73.

[4]. $\quad 4$.Amagai, M., Yamaguchi, T., Hanakawa, Y., Nishifuji, K., Sugai, M., and Stanley, J.R. (2002) Staphylococcal exfoliative toxin B specifically cleaves desmoglein1. J Invest Dermatol.118:845-50.

[5]. Baartmans, M.G., Maas, M.H., and Dokter, J. (2006) Neonate with Staphylococcal scalded skin syndrome. Arch Dis Child Fetal Neonatal Ed. 91:F25.

[6]. Cribier, B., Piemont, Y., and Grosshans, E. (1994) Staphylococcal scalded skin syndrome in adults, A clinical review illustrated with a new case. J Am Acad Dermatol.30:319-24. 
[7]. Chi, C.Y., Wang, S.M., Lin, H.C., and Liu, C.C. (2006) A clinical and microbiological comparison of Staphylococcus aureus toxic shock and scalded skin syndromes in children. Clin Infect Dis.42:181-85.

[8]. El Helali, N., Carbonne, A., Naas, T., Kerneis, S., Fresco, O., Giovangrandi, Y., Fortineau, N., Nordmann, P., and Astagneau, P. (2005) Nosocomial outbreak of Staphylococcal scalded skin syndrome in neonates: epidemiological investigation and control. J Hosp Infect.61:130-38.

[9]. Abdulmula, E.G., Khalifa, S.G., Ka, M., Hamida, E., and Abdurrahman, T. (2006) Detection of toxic shock syndrome toxin of Staphylococcus aureus from Tripoli. Libya. J Med Microbiol.55:179-82.

[10]. Su, Y.C., and Wong, A.C. (1995) Identification and purification of a new staphylococcal enterotoxin. H. Appl. Environ Microbiol.61:1438-43.

[11]. Manisha, M., Gehua, W., and Wendy, M.J. (2000) Multiplex PCR for detection of genes for Staphylococcus aureus enterotoxins, exfoliative toxins, toxic shock syndrome toxin 1, and methicillin resistance. J Clin Microbiol.38:1032-35.

[12]. Ito, Y., Funabashi, Y.M., and Toda, K. (2002) Staphylococcal scalded-skin syndrome in an adult due to methicillin-resistant Staphylococcus aureus. J Infect Chemother.8:256-61.

[13]. Kennedy, A.D, Otto, M., Braughton, K.R., Whitney, A.R., Chen, L., Mathema, B., et al. (2008) Epidemic community-associated methicillin-resistant Staphylococcus aureus: recent clonal expansion and diversification. Proc Natl Acad Sci.105:1327-32.

[14]. Stewart, P.S. (2002) Mechanisms of antibiotic resistance in bacterial biofilms. Int J Med Microbiol.292:107-13.

[15]. Astrid, L., Semir, L., and Knut, B.G. (2004) Modified multiplex PCR method for detection of pyrogenic exotoxin genes in Staphylococcal isolates. J Clin Microbiol 2004;42: 3869-72.

[16]. Murray, P.R., Baron, E.J., Jorgensen, J.H., Pfaller, M.A., and Yolken, R.H. A Short Textbook of Medical Microbiology, 4th edn. 1978. ASM Press. Washington, DC.

[17]. Ronald, M.A., Brown, A.E., Parks, L.C. In: Laboratory Manual- Experimental Microbiology. Edited by Smith JM. USA. 1995;68- 93.

[18]. Bannerman, T.L. Staphylococci and other catalase positive cocci that grow aerobically. In: Manual of clinical microbiology, 8th ed. In Murray PR, Baron EJ, Jorgenson JH, editors. ASM Press; Washington DC. 2003;384-04.

[19]. Bauer, A.W., Kirby, W.M., Sherris, J.C., and Turck, M. (1966) Antibiotic susceptibility testing by a standardized single disk method. Am J Clin Pathol.45:493-96.

[20]. Acar, J.F. The disc susceptibility test. In Antibiotics in Laboratory Medicine. Edited by Lorian VW, Wilkins B.1980; 24-25.

[21]. Watnick, P.I., Lauriano, C.M., Klose, K.E., Croal, C., and Kolter, R. (2001) The absence of a flagellum leads to altered colony morphology, biofilm development and virulence in Vibrio cholerae O139.Mol Microbiol.39:22335 .

[22]. Lauriano, C.M., Ghosh, C., Correa, N.E, and Klose KE. (2004) The sodium-driven flagellar motor controls exopolysaccharide expression in Vibrio cholera. J Bacteriol.186:4864-74.

[23]. Chakraborty, S., Garg, P., and Ramamurthy, T. et al. (2001) Comparison of antibiogram, virulence genes, ribotypes and DNA fingerprints of Vibrio cholerae of matching serogroups isolated from hospitalised diarrhoea cases and from the environment during 1997-1998 in Calcutta, India. J Med Microbiol.50:879-88.

[24]. Becker, K., Roth, R., and Peters, G. (1998) Rapid and specific detection of toxigenic Staphylococcus aureus: use of two multiplex PCR enzyme immunoassays for amplification and hybridization of staphylococcal enterotoxin genes, exfoliative toxin genes, and toxic shock syndrome toxin gene. J Clin Microbiol.36:2548-53.

[25]. Deurenberg, R.H., Vink, C., Kalenic, S., Friedrich, A.W., Bruggeman, C.A., and Stobberingh, E.E. (2007) The molecular evolution of methicillin resistant Staphylococcus aureus. Clin Microbiol Infect.13:222-35.

[26]. Ho, P.L., Chuang, S.K., Choi, Y.F., Lee, R.A., Lit, A.C., Ng, T.K., and Que, T.L. et al. (2008) Hong Kong CAMRSA surveillance network. (2008). Community-associated méthicillin-resistant and méthicilline-sensitive Staphylococcus aureus: skin and soft tissue infections in Hong Kong. Diagn Microbiol Infect Dis.61: 245-50.

[27]. Yao, D., Yu, F.Y., Qin, Z.Q., Chen, C., He, S.S., and Chen, Z.Q, et al. (2010) Molecular characterization of Staphylococcus aureus isolates causing skin and soft tissue infections (SSTIs). BMC Infect Dis.10:133.

[28]. Nagaraju, U., Bhat, G., Kuruvila, M., Pai, G.S., and Javalakshmi, R.P. (2004) Methicillin-resistant Staphylococcus aureus in community acquired pyoderma. Int J Dermatol.43:412-14.

[29]. Clauditz, A., Resch, A., Wieland, K.P., Peschel, A., and Gotz, F. (2006) Staphyloxanthin plays a role in the fitness of Staphylococcus aureus and its ability to cope with oxidative stress. Infect Immun.74:4950-53.

[30]. Duguid, J.P. Staining methods. In Mackie \& McCartney Practical Medical Microbiology. Edited by Collee JG, Fraser AG, Marmion BP, Simmons A.14th ed. Churchill Livingstone.Edinburgh. 1996;793-12.

[31]. Aarestrup, F.M., Scott, N.L., and Sordillo, L.M. (1994) Ability of Staphylococcus aureus coagulase genotypes to resist neutrophil bactericidal activity and phagocytosis. Infect Immun.62: 5679- 82.

[32]. Blair, J.E. (1962) What is a Staphylococcus? Bacteriol Rev.26: 375-81.

[33]. Sperber, W.H., and Tatini, S.R. (1975) Interpretation of the tube coagulase test for identification of Staphylococcus aureus. Appl Environ Microbiol.29: 502-05.

[34]. Gilbert, P., Allison, D.G., and McBain, A.J. (2002) Biofilms in vitro and in vivo: do singular mechanisms imply cross-resistance? Symp Ser Soc Appl Microbiol.92: 98S-110S.

[35]. Gotz, F. (2002) Staphylococcus and biofilms. Mol Microbiol.43:1367-78

[36]. Akiyama, H., Hamada, T., Huh, W.K, Yamasaki, O., Oono, T., and Fujimoto, W. et al. (2003) Confocal laser scanning microscopic observation of glycocalyx production by Staphylococcus aureus in skin lesions of bullous impetigo, atopic dermatitis and pemphigus foliaceus. Br J Dermatol.148:526-32. 
[37]. Cramton, S.E., Gerke, C., Schnell, N.F., Nichols, W.W., and Gotz, F. (1999) The intercellular adhesion (ica) locus is present in Staphylococcus aureus and is required for biofilm formation. Infect Immun.67:5427-33.

[38]. Cucarella, C., Solano, C., Valle, J., Amorena, B., Lasa, I., and Penades, J.R. (2001) Bap, a Staphylococcus aureus surface protein involved in biofilm formation. J Bacteriol.183: 2888-96.

[39]. Corrigan, R.M., Rigby, D., Handley, P., and Foster, T.J. (2007) The role of Staphylococcus aureus surface protein SasG in adherence and biofilm formation. Microbiology.153:2435-46.

[40]. O’Neill, E., Pozzi, C., Houston, P., Smyth, D., Humphreys, H., and Robinson, D.R. et al. (2007) Association between methicillin susceptibility and biofilm regulation in Staphylococcus aureus isolates from device-related infections. J Clin Microbiol.45:1379-88.

[41]. Carter, A.P., Clemons, W.M., Brodersen, D.E., Morgan, R.J., Wimberly, B.T., and Ramakrishnan, V. (2000) Functional insights from the structure of the $30 \mathrm{~S}$ ribosomal subunit and its interactions with antibiotics. Nature.407:340-48

[42]. Jevons, M.P. (1961) Celbenin-resistant staphylococci. BMJ.1:124-25.

[43]. Hiramatsu, K., Hanaki, H., Ino, T., Yabuta, K., Oguri, T., and Tenover, F.C. (1997) Methicillin-resistant Staphylococcus aureus clinical strain with reduced vancomycin susceptibility. J Antimicrob Chemother.40:135-36.

[44]. Chang, S.,Sievert, D.M.,Hageman, J.C.,Boulton, M.L.,Tenover, F.C., and Downes, F.P. et al. (2003) Infection with vancomycin-resistant Staphylococcus aureus containing the vanA resistance gene. N Engl J Med.348:1342-47.

[45]. Menichetti, F. (2005) Current and emerging serious Gram-positive infections. Clin Microbiol Infect. 3:22.-28.

[46]. Cui, L., Murakami, H., Kuwahara, K., Hanaki, H., and Hiramatsu, K. (2000) Contribution of a thickened cell wall and its glutamine nonamidated component to the vancomycin resistance expressed by Staphylococcus aureus Mu50. Antimicrob Agents Chemother.44:2276-85.

[47]. Sieradzki, K., Roberts, R.B., Haber, S.W., and Tomasz, A. (1999) The development of vancomycin resistance in a patient with methicillin-resistant Staphylococcus aureus infection. N Engl J Med.340:517-23.

[48]. Srinivasan, A., Dick, J.D., and Perl, T.M. (2002) Vancomycin resistance in staphylococci. Clin Microbiol Rev.15:430-38.

[49]. Lowy, F.D. (2003) Antimicrobial resistance: the example of Staphylococcus aureus. J Clin Invest. 111:1265-73.

[50]. Weigel, L.M., Clewell, D.B., and Gill, S.R., et al. (2003) Genetic analysis of a high-level vancomycin-resistant isolate of Staphylococcus aureus. Science.302:1569-71.

[52]. landolo, J.J. (1989) Genetic analysis of extracellular toxins of Staphylococcus aureus. Annu Rev Microbiol.43:375-02.

[53]. Sakurai, S., Suzuki, H., and Machid, K. (1995) Rapid identification by polymerase chain reaction of staphylococcal exfoliative toxin serotype A and B genes. Microbiol Immuno.39:379-86.

[54]. Johnson, W.M., Tyler, S.D., Ewan, E.P., Ashton, E.F., Pollard, D.R., and Rozee, R. (1991) Detection of genes for enterotoxins, exfoliative toxins, and toxin shock syndrome toxin 1 in Staphylococcus aureus by polymerase chain reaction. J Clin Microbiol.29:426-30.

[55]. Marrack, P., and Kappler, J. The staphylococcal enterotoxins and their relatives. Science. 248:705-11.

[56]. Lee, C.Y., Schmidt, J.J., Johnson, A.D., Spero, L., and landolo, J.J. (1987) Sequence determination and comparison of the exfoliative toxin A and toxin B genes from Staphylococcus aureus. J Bacteriol.169:3904-09.

[57]. Yamaguchi, T., Hayashi, T., Takami, H., Nakasone, K., Ohnishi, M., and Nakayama, K. et al. (2000) Phage conversion of exfoliative toxin A production in Staphylococcus aureus. Mol Microbiol.38:694-05.

[58]. Endo, Y., Yamada, T., Matsunaga, K., Hayakawa, Y., Kaidoh, T., and Takeuchi, S. (2003) Phage conversion of exfoliative toxin A in Staphylococcus aureus isolated from cows with mastitis. Vet Microbiol. 96:81-90.

[59]. Warren, R.L. (1980) Exfoliative toxin plasmids of bacteriophage group 2 Staphylococcus aureus: sequence homology. Infect Immun.30:601-06.

[60]. Yamaguchi, T., Hayashi, T., Takami, H., Ohnishi, M., Murata, T., and Nakayama, K, et al. (2001) Complete nucleotide sequence of a Staphylococcus aureus exfoliative toxin B plasmid and identification of a novel ADPribosyltransferase, EDIN-C. Infect Immun.69:7760-71.

[61]. Yamaguchi, T., Yokota, Y., Terajima, J., Hayashi, T., Aepfelbacher, M., and Ohara, M. et al. (2002) Clonal association of Staphylococcus aureus causing bullous impetigo and the emergence of new methicillin-resistant clonal groups in Kansai district in Japan. J Infect Dis.185:1511-16.

[62]. Adesiyun, A.A., Lenz, W., and Schaal, K.P. (1991) Exfoliative toxin production by Staphylococcus aureus strains isolated from animals and human beings in Nigeria. Microbiologica.14:357-62.

[63]. Ladhani, S. (2001) Recent developments in staphylococcal scalded skin syndrome. Clin Microbiol Infect.7:301-07.

[64]. Ben, N.M., Mastouri, M., Frih, S., Sakly, N., Ben, S.Y., and Nour, M. (2006) Molecular characterization of methicillin-resistant Staphylococcus aureus isolated in Tunisia. Diagn Microbiol. Infect Dis.55:21-26.

[65]. Loughman, J.A., Fritz, S.A., Storch, G.A., and Hunstad, D.A. (2009) Virulence gene expression in human community-acquired Staphylococcus aureus infections. J Infect Dis.199:294-01.

[66]. Buckingham, S.C., McDougal, L.K., Cathey, L.D., Comeaux, K., Craig, A.S., and Fridkin, S.K. et al. (2004) Emergence of community-associated methicillin - resistant Staphylococcus aureus at a Memphis, Tennessee Children's Hospital. Pediatr Infect Dis J.23:619-24.

[67]. Fridkin, S.K., Hageman, J.C., Morrison, M., Sanza, L.T., Como-Sabenti, K., and Jernigan, J.A. et al. (2005) Active Bacterial Core Surveillance Program of the Emerging Infections Program Network. Methicillin-resistant Staphylococcus aureus disease in three communities. N Engl J Med.352:1436-44.

[68]. Trystam, D., Varon, E., Pean, Y., Grundmann, H., Gutmann, L., and Jarlier, V. et al. (2004) European Antimicrobial Resistance Surveillance System (EARSS):reference data of 2002; France. 2004BEH. 32-33: 142-44. 
FIG. 1

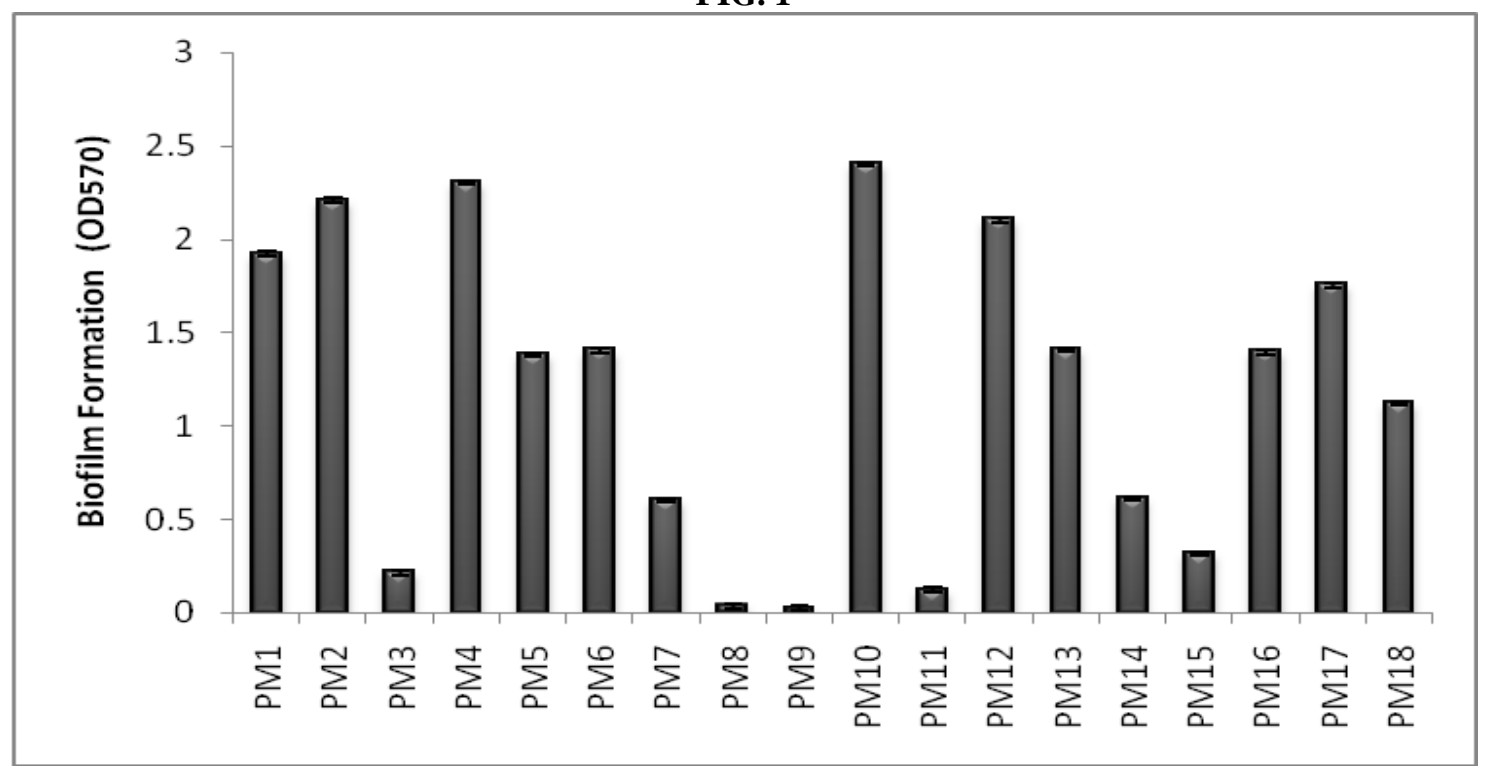

A comparison of $18 \mathrm{~h}$ biofilms made by Staphylococcus aureus. Biofilms stained with crystal violet and quantification of biofilm-associated crystal violet is shown here. Error bars are standard errors of means.

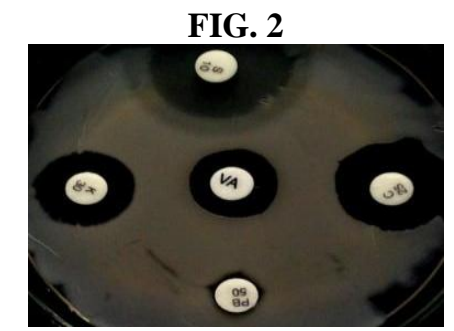

Sensitivity of strain PM4 towards antibiotic vancomycin, polymyxin B, chloramphenical, streptomycin and kanamycin. Bacterial smear was prepared on nutrient agar plate and inhibitory zone was measured using standard procedure.

FIG. 3

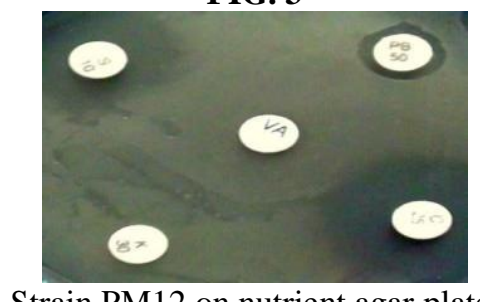

Strain PM12 on nutrient agar plate.

FIG. 4

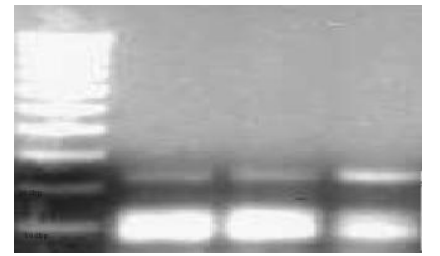

Agarose gel electrophoresis of multiplex PCR products showing 119bp and 228bp band represent etA and 16S rRNA respectively of strain PM4, PM7 and PM12.

Table-1: Staphylococcus aureus exotoxin-specific oligonucleotide primer sequences.

\begin{tabular}{lll}
\hline Target Gene & Oligonucleotide Sequence (5'-3')
\end{tabular}


Analysis of virulence potentials of community acquired staphylococcus aureus, isolated from a slam...

\begin{tabular}{lll}
\hline$s e A-\mathrm{F}$ & GCAGGGAACAGCTTTAGGC & Astrid et al. 2004 \\
$s e A-\mathrm{R}$ & GTTCTGTAGAAGTATGAAACACG & Astrid et al. 2004 \\
$s e B-\mathrm{F}$ & ACATGTAATTTTGATATTCGCACTG & Astrid et al. 2004 \\
$s e B-\mathrm{R}$ & TGCAGGCATCATGTCATACCA & Astrid et al. 2004 \\
$e t A-\mathrm{F}$ & CTAGTGCATTTGTTATCAAGACG & Becker et al. 1998 \\
$e t A-\mathrm{R}$ & TGCATTGACACCATAGTACTTATTC & Becker et al. 1998 \\
$e t B-\mathrm{F}$ & ACGGCTATATACATTCAATTCAATG & Becker et al. 1998 \\
$e t B-\mathrm{R}$ & AAAGTTATTCATTTAATGCACTGTCTC & Becker et al.1998 \\
$t s s T-\mathrm{F}$ & GCTTGCGACAACTGCTACAG & Astrid et al. 2004 \\
$t s s T-\mathrm{R}$ & TGGATCCGTCATTCATTGTTAT & Astrid et al. 2004 \\
$16 \mathrm{~s}$ rRNA-F & GTAGGTGGCAAGCGTTATCC & Astrid et al. 2004 \\
$16 \mathrm{~s}$ rRNA-R & CGCACATCAGCGTCAG & Astrid et al. 2004
\end{tabular}

$\mathrm{F}$ indicate forward primer, $\mathrm{R}$ indicate reverse primer (Astrid et al. 2004; Becker et al. 1998)

Table-2: Biochemical Characterization of Staphylococcus aureus.

\begin{tabular}{|c|c|c|c|c|c|c|c|}
\hline $\begin{array}{c}\text { Sample } \\
\text { No. }\end{array}$ & $\begin{array}{l}\text { Gram } \\
\text { Stain }\end{array}$ & $\begin{array}{l}\text { Catalase } \\
\text { Ability }\end{array}$ & $\begin{array}{c}\text { Coagulase } \\
\text { Ability }\end{array}$ & $\begin{array}{l}\text { Urease } \\
\text { Ability }\end{array}$ & $\begin{array}{c}\text { Gelatinase } \\
\text { Ability }\end{array}$ & $\begin{array}{c}\text { Growth on } \\
\text { MacConkey } \\
\text { Agar }\end{array}$ & $\begin{array}{c}\text { Hemolysin } \\
\text { Ability }\end{array}$ \\
\hline PM1 & + & + & + & + & + & + & + \\
\hline PM2 & + & + & + & + & + & - & + \\
\hline PM3 & + & + & + & + & + & + & + \\
\hline PM4 & + & + & - & + & + & + & - \\
\hline PM5 & + & + & + & + & + & - & + \\
\hline PM6 & + & + & - & + & + & - & - \\
\hline PM7 & + & + & + & + & + & - & + \\
\hline PM8 & + & + & + & + & + & - & + \\
\hline PM9 & + & + & + & + & + & - & + \\
\hline PM10 & + & + & - & + & + & - & - \\
\hline PM11 & + & + & + & + & + & + & + \\
\hline PM12 & + & + & + & + & + & - & + \\
\hline PM13 & + & + & + & + & + & + & + \\
\hline PM14 & + & + & + & + & + & - & + \\
\hline PM15 & + & + & + & + & + & + & - \\
\hline PM16 & + & + & + & + & + & - & + \\
\hline PM17 & + & + & + & + & + & - & + \\
\hline PM18 & + & + & + & + & + & - & + \\
\hline
\end{tabular}

Table 3: Susceptibility of Staphylococcus aureus to 10 antimicrobial agents.

\begin{tabular}{lcc}
\hline Antibiptic & $(\%)$ Sensitive & $(\%)$ Resistant \\
\hline Ampicillin(30mcg) & 38.88 & 61.12 \\
Streptomycin(10mcg) & 66.66 & 33.34 \\
Kanamycin(30mcg) & 83.33 & 16.67 \\
Chloramphenicol(25mcg) & 83.33 & 16.67 \\
Tetracycline(50mcg) & 44.44 & 55.56 \\
Polymixin B(50mcg) & 88.88 & 11.12 \\
Oxacillin(1mcg) & 55.55 & 44.45 \\
Methicillin(10mcg) & 66.66 & 33.34 \\
Vancomycin(30mcg) & 77.77 & 22.23 \\
Novobiocin(30mcg) & 88.88 & 11.12 \\
\hline
\end{tabular}

